\title{
Antibacterial and Cytotoxic Activity of Longiverbenone Isolated from the Rhizome of Cyperus scariosu
}

\author{
M Shafiqur Rahman* and M Nural Anwar \\ Department of Microbiology, University of Chittagong, Chittagong 4331, Bangladesh
}

[Received 01 April 2008; Accepted 14 June 2008]

\begin{abstract}
Longiverbenone is a naturally occurring sesquiterpene isolated from ethanolic extract of Cyperus scariosus rhizome by solvent-solvent portioning and chromatographic technique. The antibacterial activity of longiverbenone was evaluated against eleven potential human pathogenic bacteria using disc diffusion method. Minimum inhibitory concentration (MIC) and minimum bactericidal concentration (MBC) were determined by broth macrodilution method. Cytotoxic activity (lethal concentration $50 \%$, $\mathrm{LC}_{50}$ ) of longiverbenone was determined on new borne brine shrimp (Artemia salina). Longiverbenone showed moderate to good antibacterial activity against the test organisms tested herein. It exhibited the lowest MIC (20 $\mu \mathrm{g} / \mathrm{ml})$ and $\mathrm{MBC}(80 \mu \mathrm{g} / \mathrm{ml})$ against Vibrio cholerae. The $\mathrm{LC}_{50}$ of the isolated sesquiterpene was found to be $14.38 \mu \mathrm{g} / \mathrm{ml}$ against new borne brine shrimp.
\end{abstract}

Keywords: Antibacterial activity, Cytotoxic activity $\left(\mathrm{LC}_{50}\right)$, Cyperus scariosu, Longiverbenone, Minimum inhibitory concentration (MIC)

Plants are still widely used in ethnomedicine around the world. Among the different plant-derived secondary metabolites proved to be the most important group of compounds that showed wide range of antimicrobial activity ${ }^{1-2}$. Microorganisms have developed resistance against many antibiotics and this has created immense clinical problems in the treatment of infectious diseases ${ }^{3}$. This situation forced scientists to search for new antimicrobial substances from various sources, such as medicinal plants. So, there is a continuing need for new antimicrobial agents since none of the available drugs is free from adverse effects and limitation. So, intensive antibacterial and phytochemical investigation is needed in this field.

Cyperus scariosus $\mathrm{Br}$. is a small grass-like herb with angular soft stem and underground rhizomatous tubers and belongs to the family of Cyperaceae. This herb grows plentifully and almost everywhere in Bangladesh as noxious weeds. In tribal areas of Bangladesh, rhizome of C. scariosus is widely used as a phytotherapeutic agent against dysentery. The rhizome of this plant contains an amber or light brown viscous essential oil and the extract of the tuber is used as a remedy for fever, diarrhoea, dysentery, cholera and vomiting ${ }^{4}$. The aim of the present work is to evaluate the antimicrobial activity of a pure compound from C. scariosus on several pathogenic bacteria, which can cause diseases in man.

Rhizomes of C. scariosus were collected from a local garden owned by the Bangladesh Council of Scientific and Industrial Research (BCSIR) Laboratories, Chittagong, in December 2004 and it was identified by Dr. M Yousuf of BCSIR, where a voucher specimen (No. 1564a) has been maintained. The collected sample was cleaned, cut into small $(1-2 \mathrm{~cm})$ pieces, dried at $50-55^{\circ} \mathrm{C}$, pulverized and then $250 \mathrm{~g}$ of the dried powder was kept steeped twice overnight in ethanol. The extract thus obtained was filtered, centrifuged at 5,000 rpm for $20 \mathrm{~min}$ and then concentrated to a gummy material $(12.5 \mathrm{~g} ; 5 \% \mathrm{w} / \mathrm{w})$ under reduced pressure at $50^{\circ} \mathrm{C}$ by rotary vacuum evaporator.

Solvent-solvent partitioning of concentrated crude extract was done using the protocol designed by Kupchan and modified by Wagenen ${ }^{5}$. All the fractions were collected separately, dried as usual and tested for any of their antimicrobial efficacy. Of these, only the crude petroleum ether extract fraction showing high antimicrobial activity was subjected to fractionation by column chromatography using silica gel (200-300 mesh) as the adsorbent. From it a total of 24 fractions were collected separately using mixtures containing different proportions of petroleum ether and ethyl acetate with increasing polarity as the eluants. The column-separated fractions thus obtained were examined using thin-layer chromatography (TLC) technique and ultraviolet light (254 and $366 \mathrm{~nm}$ ) to detect the presence of any fluorescent compound. The $\mathrm{R}_{\mathrm{f}}$-values for each were measured as usual. Fractions showing same $\mathrm{R}_{\mathrm{f}}$-value were mixed together and grouped into eight fractions $\left(\mathrm{C}_{1}-\mathrm{C}_{8}\right)$.

All the fractions $\left(\mathrm{C}_{1}-\mathrm{C}_{8}\right)$ were tested against a highly sensitive bacterium (Bacillus megaterium) and a fungus (Aspergillus niger). Of these, the highly antibacterial and antifungal fraction $\mathrm{C}_{1}$, eluted in petroleum ether, yielded $2.56 \mathrm{~g}(1.024 \% \mathrm{w} / \mathrm{w})$ of greenish

${ }^{*}$ Corresponding author:

Dr. M Shafiqur Rahman, Associate Professor \& Chairman, Department of Microbiology, University of Chittagong, Chittagong 4331, Bangladesh

Tel (Office): (031) 726311-14, Ext 4464; Cell: 01711 959996; Fax: +880 (031) 726310; E-mail: rahmanms68@yahoo.com 
brown oil. This oil, on various spectroscopic (e.g., IR, NMR and GCMS) analyses and on comparison of such analytical results with NYST Library data, was identified as longiverbenone, which is a sesquiterpene. NMR and GSMS were performed on respectively a Bruker spectrospin spectrometer and a GC-17A Ver. 3 gas chromatography coupled to a Shimadzu mass spectrometer (Model QP 5050A).

The in vitro antibacterial activities of the column separated fractions and of the chemically isolated pure compound longiverbenone of the plant were determined against eleven potential human pathogenic bacteria by disc diffusion method ${ }^{6}$. using MuellerHinton (agar and broth) medium. All the results were compared with the standard antibacterial antibiotic ampicillin (20 $\mu \mathrm{g} / \mathrm{disc})$. Minimum inhibitory concentration (MIC) and minimum bactericidal concentration (MBC) were determined by macrodilution broth technique ${ }^{7}$. The $\mathrm{LC}_{50}$ test was performed on new born brine shrimp (Artemia salina) according to an established method $^{8}$. The median lethal concentration $50 \%\left(\mathrm{LC}_{50}\right)$ of the test compound (1.5625 to $200 \mu \mathrm{g} / \mathrm{ml}$ water) was calculated by trend line fit linear regression analysis of the experimentally obtained data.

All the experimentally observed spectroscopic data of fraction $C_{1}$ were found to resemble very closely to the presence of the compound longiverbenone (a sesquiterpene). The compound was obtained as greenish brown oil. Its molecular weight and chemical formula were found to be 218 and $\mathrm{C}_{15} \mathrm{H}_{22} \mathrm{O}$ respectively.

Different concentrations of longiverbenone were screened for their antibacterial activity against the test organisms and the results are summarized in Table 1. It appeared that the compound gave moderate to good antibacterial activity against all the test bacteria except P. aeruginisa and S. aureus. The largest zone of inhibitions 30, 22, 15 and $8 \mathrm{~mm}$ in diameter were recorded against Vibrio cohlearae at the concentration of 160, 80, 40 and $20 \mu \mathrm{g} /$ disc respectively. Standard antibacterial antibiotic ampicillin ( $20 \mu \mathrm{g} /$ disc) was also found to be active against all the bacteria tested herein except $P$. aeruginosa.

Table 1. Antibacterial activity of longiverbenone isolated from rhizome of Cyperus scariosus

\begin{tabular}{lcccccc}
\hline Test organism & \multicolumn{5}{c}{ Diameter of zone of inhibition (mm) } \\
\cline { 2 - 6 } & \multicolumn{5}{c}{$\begin{array}{c}\text { Longiverbenone } \\
(\mu \mathrm{g} / \mathrm{disc})\end{array}$} & $\begin{array}{c}\text { Ampicillin } \\
(20 \mu \mathrm{g} / \mathrm{disc})\end{array}$ \\
\cline { 2 - 6 } & 160 & 80 & 40 & 20 & 10 & \\
\hline Bacillus subtilis & 25 & 14 & 7 & 0 & 0 & 19 \\
Bacillus cereus & 26 & 17 & 12 & 7 & 0 & 18 \\
Bacillus megaterium & 25 & 14 & 7 & 0 & 0 & 16 \\
Staphylococcus aureus & 0 & 0 & 0 & 0 & 0 & 22 \\
Escherichia coli & 15 & 10 & 0 & 0 & 0 & 10 \\
Vibrio cholerae & 30 & 22 & 15 & 8 & 0 & 15 \\
Shigella dysenteriae & 24 & 13 & 8 & 0 & 0 & 22 \\
Shigella sonnei & 10 & 6 & 0 & 0 & 0 & 20 \\
Salmonella typhi & 15 & 8 & 0 & 0 & 0 & 20 \\
Salmonella paratyphi & 12 & 10 & 6 & 0 & 0 & 17 \\
Pseudomonas aeruginosa & 0 & 0 & 0 & 0 & 0 & 0 \\
\hline
\end{tabular}

The MIC and MBC values of the sesquiterpene of $C$. scariosus rhizome are presented in Table 2. The MIC values of the compound longiverbenone were $20 \mu \mathrm{g} / \mathrm{ml}$ against $V$. cholerae, $40 \mu \mathrm{g} / \mathrm{ml}$ against Bacillus subtilis, B. cereus, B. megaterium and S. dysenteriae, $80 \mu \mathrm{g} / \mathrm{ml}$ against E. coli and S. paratyphi, and $160 \mu \mathrm{g} / \mathrm{ml}$ against S. sonnei and S. typhi. S. aureus was found to resistant to the agent showing growth in the presence of the highest concentration used $(320 \mu \mathrm{g} / \mathrm{ml})$. The MBC values of the agent varied between 80 and $320 \mu \mathrm{g} / \mathrm{ml}$ in case of eight organisms with the lowest $(80 \mu \mathrm{g} / \mathrm{ml})$ against $V$. cholerae. Similar antibacterial activity of plant essential oils and sesquiterpenes has been reported previously ${ }^{9-10}$.

Table 2. Minimum inhibitory concentration (MIC) and minimum bactericidal concentration (MBC) of longiverbenone isolated from rhizome of Cyperus scariosus against eleven pathogenic bacteria

\begin{tabular}{lcc}
\hline Test organism & $\begin{array}{c}\text { MIC value } \\
(\mu \mathrm{g} / \mathrm{ml})\end{array}$ & $\begin{array}{c}\text { MBC value } \\
(\mu \mathrm{g} / \mathrm{ml})\end{array}$ \\
\hline Bacillus subtilis & 40 & 160 \\
Bacillus cereus & 40 & 160 \\
Bacillus megaterium & 40 & 320 \\
Staphylococcus aureus & $\mathrm{NF}$ & $\mathrm{NF}$ \\
Escherichia coli & 80 & 320 \\
Vibrio cholerae & 20 & 80 \\
Shigella dysenteriae & 40 & 160 \\
Shigella sonnei & 160 & $\mathrm{NF}$ \\
Salmonella typhi & 160 & 320 \\
Salmonella paratyphi & 80 & 320 \\
Pseudomonas aeruginosa & 320 & $\mathrm{NF}$ \\
\hline
\end{tabular}

$\mathrm{NF}=$ Not found.

The cytotoxic activity $\left(\mathrm{LC}_{50}\right)$ of the compound longiverbenone new born brine shrimp (Artemia salina) is presented in Table 3. The $\mathrm{LC}_{50}$ of the compound against the brine shrimp was found to be $14.38 \mu \mathrm{g} / \mathrm{ml}$. The cytotoxic bioassay result of longiverbenone may lead to the exploration of its potential and practical application as a novel less toxic and antimicrobial compound from this plant. Similar cytotoxic activities of plant constituents have been reported previously ${ }^{11}$.

Table 3. Cytotoxic activity $\left(L C_{50}\right)$ of longiverbenone on brine shrimp (Artemia salina) ${ }^{a}$

\begin{tabular}{|c|c|c|c|c|}
\hline \multirow{2}{*}{$\begin{array}{l}\text { Longiverbenone } \\
(\mu \mathrm{g} / \mathrm{ml})\end{array}$} & \multirow{2}{*}{$\begin{array}{c}\text { Log of } \\
\text { concentration }\end{array}$} & \multicolumn{2}{|c|}{ Mortality after 24 h (\%) } & \multirow{2}{*}{$\begin{array}{c}\mathrm{LC}_{50} \\
(\mu \mathrm{g} / \mathrm{ml})\end{array}$} \\
\hline & & Longiverbenone & Control & \\
\hline 1.5625 & 0.1938 & 0 & & \\
\hline 3.125 & 0.4949 & 10 & & \\
\hline 6.25 & 0.7959 & 30 & & \\
\hline 12.5 & 1.0969 & 40 & 0 & 14.38 \\
\hline 25 & 1.3979 & 70 & & \\
\hline 50 & 1.6960 & 90 & & \\
\hline 100 & 2.0000 & 100 & & \\
\hline 200 & 2.3010 & 100 & & \\
\hline
\end{tabular}


Research on natural resources has been encouraged by the World Health Organization (WHO) since last three decades. It is evident from this study that longiverbenone isolated from $C$. scariosus rhizome exhibited moderate to good antibacterial activity against the organisms tested herein. Our results could stimulate further pharmacological studies seeking new antimicrobial agents from the plant resources.

\section{Acknowledgement}

The authors wish to thank to Dr. Jaripa Begum, Mr. Jasim Uddin Chowdhury and Dr. M Yousuf, Bangladesh Council for Scientific and Industrial Research (BCSIR), Chittagong, Bangladesh for supplying the samples, spectroscopic recording and analysis of the isolated compound.

\section{References}

1. Raman MS, Anwar MN \& Chowdhury AZMS. 1999. Antibacterial activity of secondary metabolites from Holarrhena antidysenterica stem bark. Bangladesh J Microbiol. 16(2): 101-105.

2. Sarkar SD, Muniruzzaman S \& Khan SI. 1991. Antimicrobial activity of Piper chaba Hunter (Chui). Bangladesh J Bot. 20(2): 179-182.
3. Davis J. 1994. Inactivation of antibiotics and the dissemination of resistance genes. Science. 264: 375-382.

4. Ghani A. 1998. Medicinal Plants of Bangladesh: Chemical Constituents and Uses, $1^{\text {st }}$ edn, pp 195-196. Asiatic Society of Bangladesh, Dhaka.

5. Wagenen BC, Larsen RJS, Cardellina HD, Randazzo ZCI \& Justisatienr A. 1933. Ulo santion, a potent insecticide from the sponge Ulosa ruetleri. Organic Chem. 58: 335-337.

6. Bauer AW, Kirby MM, Sherris JC \& Turck M. 1966. Antibiotic susceptibility testing by a standardized single disc method. Am J Clin Path. 45: 493-496.

7. Jones NR, Barry LA, Gavan LT \& Washington JA. 1985. Manual of Clinical Microbiology, $4^{\text {th }}$ edn, pp 972-976. American Society for Microbiology, Washington DC.

8. Meyer BN, Ferrigni NR, Putman JE, Jacobson LB, Bichols DE \& McLaughlin JL. 1982. Brine shrimp: A convenient bioassay for active constituents. Planta Med. 45: 31-34.

9. Aureli P, Costantini A \& Zolea S. 1992. Antimicrobial activity of some plant essential oils against Listeria monocytogenes. J Food Product. 55: 344-348.

10. Habtemariam S, Gray AI \& Waterman PG. 1993. A new antibacterial sesquiterpene from Premna oligotricha. J Natural Product. 56: 140-143.

11. Chowdhury AA, Khan OF, Rahman MT, Islam MS. 2003. Cytotoxic and antitumor activity of Trema orientalis. Dhaka Univ J Pharma Sci. 1(1-2): 55-58. 